\title{
RESIKO YURIDIS ASURANSI SOSIAL BAGI PEGAWAI PT TASPEN (PERSERO) KANTOR CABANG UTAMA SEMARANG YANG MENGAJUKAN PENSIUN DINI
}

\author{
Oleh \\ Rahmat Al Hafidh, Fitika Andraini
}

\begin{abstract}
PT TASPEN (PERSERO) is an Indonesian State-Owned Enterprise engaged in pension fund insurance and taboo PT TASPEN (PERSERO) is an Indonesian State-Owned Enterprise engaged in insurance for pension funds and old age savings which refers to Government Regulation Number 20 of 2013 About Amendments to Government Regulation Number 25 of 1981 concerning Civil Servants' Social Insurance. PT TASPEN (PERSERO) in carrying out its role is not always able to fulfill the rights of Civil Servants on pension rights and old age savings because of the things that are needed in the fulfillment of pension rights and old age savings. These matters are concerning the role of PT TASPEN (PERSERO) in organizing pension and old-age savings programs that will later be entitled to receive severance pay and receive other pension rights based on applicable regulations.

The problem in this study is about the risk of social insurance juridical for employees of PT TASPEN (PERSERO) Semarang Main Branch Office who apply for early retirement before the specified retirement age limit.

This research is a type of normative juridical research that focuses on studying the application of positive legal norms or norms.

From the results of this study indicate that, the juridical risk when applying for an early retirement is not legal unless the person concerned is in trouble, at the time of retirement will get administrative sanctions in the form of postponement of retirement or severance pay.

With old age referring to Government Regulation Number 20 of 2013 concerning Amendments to Government Regulation Number 25 of 1981 concerning Civil Servants' Social Insurance. PT TASPEN (PERSERO) in carrying out its role is not always able to fulfill the rights of Civil Servants on pension rights and old age savings because of the things that are needed in the fulfillment of pension rights and old age savings. These matters are concerning the role of PT TASPEN (PERSERO) in organizing pension and old-age savings programs that will later be entitled to receive severance pay and receive other pension rights based on applicable regulations.
\end{abstract}


Keywords: Social Insurance, Early Retirement, TASPEN

\begin{abstract}
ABSTRAK
PT TASPEN (PERSERO) merupakan Badan Usaha Milik Negara Indonesia yang bergerak di bidang asuransi dana pensiun dan tabungan hari tua yang mengacu pada Peraturan Pemerintah Nomor 20 Tahun 2013 Tentang Perubahan Atas Peraturan Pemerintah Nomor 25 Tahun 1981 Tentang Asuransi Sosial Pegawai Negeri Sipil. PT TASPEN (PERSERO) dalam menjalankan perannya tidak selalu mampu memenuhi hak Pegawai Negeri atas hak pensiun dan tabungan hari tua karena adanya hal - hal yang diperlukan dalam pemenuhan atas hak pensiun dan tabungan hari tua. Hal - hal tersebut mengenai peran PT TASPEN (PERSERO) dalam menyelenggarakan program dana pensiun dan tabungan hari tua yang nantinya berhak menerima pesangon dan menerima hak hak pensiun lainnya berdasarkan peraturan yang berlaku.

Permasalahan dalam penelitian ini mengenai resiko yuridis asuransi sosial bagi pegawai PT TASPEN (PERSERO) Kantor Cabang Utama Semarang yang mengajukan pensiun dini sebelum batas usia pensiun yang telah tentukan.

Penelitian ini, merupakan tipe penelitian yuridis normatif yaitu penelitian yang difokuskan untuk mengkaji penerapan kaidah - kaidah atau norma - norma dalam hukum positif.

Dari hasil penelitian ini menunjukkan bahwa, resiko yuridis saat pengajuan pensiun dini tidak ada akibat hukum kecuali orang yang bersangkutan bermasalah, pada saat pensiun akan mendapatkan sanksi administratif bisa berupa penundaan pensiun atau pesangon.
\end{abstract}

\title{
Kata Kunci : Asuransi Sosial, Mengajukan Pensiun Dini, TASPEN
}

\section{PENDAHULUAN}

Manusia dalam kehidupannya maupun dalam kegiatannya selalu menunjukkan suatu sifat alamiah yang mengakibatkan adanya suatu keadaan yang tidak dapat diramalkan terlebih dahulu, sehingga tidak pernah ada rasa pasti dari keadaan tersebut. Keadaan yang tidak pasti tersebut dapat berwujud dalam berbagai bentuk dan peristiwa yang biasanya selalu dihindari. Keadaan ini akan menimbulkan rasa tidak aman yang nantinya keadaan ini disebut dengan risiko. Kalau kita mendengar kata risiko, kita akan membayangkan suatu gambaran ditimpa suatu kerugian. Seseorang memikirkan dan melakukan usaha untuk mengatasi risiko itu supaya tidak ditimpa kerugian, kalau kerugian itu dapat disingkirkan itulah 
yang paling ideal. Tetapi kalau tidak, kita akan selalu dihadapkan dengan risiko - risiko.

Asuransi atau pertanggungan merupakan sebuah pengalihan risiko. Risiko tersebut merupakan suatu hal yang tidak dapat dipastikan terjadi kapan saja dan dimana saja. Seperti yang dikatakan oleh S.R. Diacon dan R.L. Carter bahwa"Risiko itu ada setiap kali orang tidak dapat menguasai dengan sempurna atau mengetahui lebih dulu mengenai masa depan"1

Menghindari risiko adalah suatu cara menghadapi masalah yang penuh risiko. Cara mencegah risiko, suatu risiko itu mungkin akan teratasi sehingga beberapa akibat - akibat yang jelek dan tidak dikehendaki akan dapat dihindari. Memperalihkan risiko adalah suatu risiko yang dialihkan pada pihak lain. Dengan cara yang keempat adalah menerima risiko dengan cara ini apabila risiko yang diperkirakan tidak terlalu besar atau usaha - usaha menghindari, mencegah, dan memperalihkan itu diperhitungkan lebih besar dari pada keuntungannya maka orang yang menghadapi risiko mungkin mengambil sikap bahwa ia akan menerima atau pasrah saja.

Fungsi utama asuransi adalah sebagai pengalihan risiko, pengumpulan dana dan premi yang

\footnotetext{
${ }^{1}$ S.R. Diacon dan R.L. Carter dalam Sri Rejeki Hartono, Hukum Asuransi dan Perusahaan Asuransi, Jakarta: Sinar Grafika, 2005, hlm 58
}

seimbang. Fungsi sekunder asuransi adalah untuk merangsang pertumbuhan usaha, mencegah kerugian, pengendalian kerugian, memiliki manfaat sosial dan sebagai tabungan. Sedangkan fungsi tambahan asuransi adalah sebagai investasi dana. Tidak semua risiko dapat diasuransikan.

Selain itu, meskipun banyak metode untuk menangani risiko, asuransi merupakan metode yang paling banyak dipakai. Karena asuransi menjanjikan perlindungan kepada pihak tertanggung terhadap risiko yang dihadapi perorangan maupun risiko yang dihadapi oleh perusahaan.

Karena dipandang pentingnya asuransi bagi masyarakat maka kebutuhan akan jasa perasuransian makin dirasakan, baik oleh perorangan maupun dunia usaha di Indonesia. Asuransi merupakan sarana finansial dalam tata kehidupan rumah tangga, baik dalam menghadapi risiko mendasar seperti risiko kematian, atau dalam menghadapi risiko atas harta benda yang dimiliki. Demikian pula dunia usaha dalam menjalankan kegiatannya menghadapi berbagai risiko yang mungkin dapat mengganggu kesinambungan usahanya.

Pasal 1 angka 1 Undang Undang Nomor 40 Tahun 2014 tentang Perasuransian. Asuransi adalah perjanjian antara dua pihak, yaitu perusahaan asuransi dan 
pemegang polis, yang menjadi dasar bagi penerimaan premi oleh perusahaan asuransi sebagai imbalan untuk :

a. Memberikan penggantian kepada tertanggung atau pemegang polis karena kerugian, kerusakan, biaya yang timbul, kehilangan keuntungan, atau tanggung jawab hukum kepada pihak ketiga yang mungkin diderita tertanggung atau pemegang polis karena terjadinya suatu peristiwa yang tidak pasti; atau

b. Memberikan pembayaran yang didasarkan pada meninggalnya tertanggung atau pembayaran yang didasarkan pada hidupnya tertanggung dengan manfaat yang besarnya telah ditetapkan atau didasarkan pada hasil pengelolaan dana.

Peran serta asuransi dalam pembangunan nasional semakin meningkat dengan disertai berbagai tantangan dan risiko yang dihadapinya. Oleh karena itu asuransi perlu diberikan perlindungan, pemeliharaan, dan peningkatan kesejahteraannya, sehingga pada gilirannya akan dapat meningkatan produktivitas nasional. Asuransi mempunyai tujuan untuk mengalihkan segala risiko yang ditimbulkan peristiwa - peristiwa yang tidak dapat diharapkan terjadinya itu kepada orang lain yang mengalami risiko itu untuk mengganti kerugian.
Salah satu bidang asuransi didalam dekade terakhir ini cukup mendapat perhatian publik, baik dari kalangan akademisi maupun praktisi di bidang asuransi, yakni asuransi sosial (social insurance). Bagi Negara yang menganut faham Negara kesejahteraan (welfare state), salah satu yang menjadi indikator tercapainya tujuan Negara adalah tersedianya jaminan sosial (social security) bagi masyarakat.

PT. TASPEN (PERSERO) adalah suatu Badan Usaha Milik Negara yang ditugaskan oleh pemerintah untuk menyelenggarakan Asuransi Sosial Pegawai Negeri Sipil, yaitu suatu asuransi yang memberikan jaminan keuangan bagi peserta yang diterima pada saat yang bersangkutan berhenti karena pensiun. PT. TASPEN (PERSERO) yang dibentuk oleh pemerintah berdasarkan Peraturan Pemerintah Nomor 20 Tahun 2013 Perubahan Atas Peraturan Pemerintah Nomor 25 Tahun 1981 yang tujuan dan usahanya adalah menyelenggarakan Asuransi Sosial Pegawai Negeri Sipil yang secara administratif bertugas mengelola program pensiun, sesuai dengan maksud dan tujuannya, maka peserta Taspen adalah seluruh Pegawai Negeri.

Sebagai organisasi bisnis maupun lembaga pelayanan PT. TASPEN (PERSERO) mengemban amanat dari pemerintah untuk mengelola dana tabungan para Pegawai Negeri yang di potong dari 
gaji serta mengamankan dana tersebut bagi kepentingan pembayaran pensiun dan tabungan hari tua Pegawai Negeri yang kelak dibayarkan kalau ia memasuki masa pensiun.

\section{METODOLOGI PENELITIAN}

\subsection{Tipe Penelitian}

Metode yang digunakan dalam penelitian ini adalah metode pendekatan Yuridis Normatif. Pada penelitian hukum jenis ini, sering kali hukum dikonsepkan sebagai apa yang tertulis dalam peraturan perundang-undangan (law in books) atau hukum yang dikonsepkan sebagai kaidah atau norma yang merupakan patokan berperilaku manusia yang dianggap pantas. Oleh karena itu, sumber datanya hanyalah data sekunder (bahan kepustakaan) ${ }^{2}$. Tahapan pertama penelitian hukum normatif adalah penelitian yang ditujukan untuk mendapatkan hukum obyektif (norma hukum), yaitu dengan mengadakan penelitian terhadap masalah hukum. Tahapan kedua penelitian hukum normatif adalah penelitian yang ditujukan untuk mendapatkan hukum subyektif (hak dan kewajiban).

\subsection{Spesifikasi Penelitian}

Spesifikasi penelitian yang dipakai dalam penelitian ini adalah deskriptif analisis yaitu penelitian

${ }^{2}$ Amiruddin, Pengantar Metode Penelitian Hukum, Jakarta: Raja Grafindo Persada, 2013,

hlm 118 yang bertujuan untuk memberikan gambaran secara rinci, sistematis dan menyeluruh mengenai segala sesuatu yang berhubungan dengan peraturan perundangan-undangan yang berlaku, selanjutnya dianalisa dengan teori hukum akurat dan sesuai fakta mengenai Resiko Yuridis Asuransi Sosial Bagi Pegawai PT. TASPEN (PERSERO) Kantor Cabang Utama Semarang yang Mengajukan Pensiun Dini.

\subsection{Sumber Data}

Penulisan skripsi ini menggunakan sumber data sekunder, yaitu data yang diperoleh langsung dari buku - buku, laporan, arsip maupun berbentuk dokumen yang diambil dari PT. TASPEN (PERSERO) Kantor Cabang Utama Semarang. Data sekunder berupa berbagai bahan pustaka yang memaparkan segala sesuatu mengenai asuransi sosial dalam lingkup pegawai PT. TASPEN (PERSERO).

\subsection{Metode Pengumpulan Data}

Metode pengumpulan data dilakukan dengan cara interview dan studi pustaka serta literature. Maka peneliti dalam penelitian ini menggunakan metode pustaka (penelitian hukum kepustakaan) ${ }^{3}$ yaitu:

1) Studi Kepustakaan 
Pengumpulan data di dapat dari studi kepustakaan, dengan menggunakan peraturan perundang undangan serta literature yang berkaitan dengan Resiko Yuridis Asuransi Sosial Bagi Pegawai PT. TASPEN (PERSERO) Kantor Cabang Utama Semarang yang Mengajukan Pensiun Dini.

2) Wawancara

Wawancara dilakukan dengan petugas operasional PT. TASPEN (PERSERO) Kantor Cabang Utama Semarang, dan hasil wawancara ini dijadikan dokumen pendukung bahan sekunder. Wawancara hanya digunakan sebagai pelengkap data.

\subsection{Metode Penyajian Data}

Metode penyajian data yang digunakan dalam penelitian ini dengan cara pemaparan (deskriptif) menggambarkan dan menjelaskan sesuai fakta yang terjadi pada objek penelitian secara terperinci tepat dan jelas untuk mendapatkan kejelasan atas masalah yang ada, dalam penelitian ini menjelaskan dan menguraikan data yang disajikan mengenai Resiko Yuridis Asuransi Sosial Bagi Pegawai PT. TASPEN (PERSERO) Kantor Cabang Utama Semarang yang Mengajukan Pensiun Dini.

\subsection{Metode Analisis Data}

Metode analisis data dalam penulisan ini diperoleh dari penelitian yang akan dianalisis secara kualitatif, yaitu dengan menganalisis data - data yang ada berdasarkan teori - teori yang berkaitan dengan masalah yang diteliti, kemudian apa yang dikemukakan oleh responden, baik lisan maupun tertulis, diteliti dan dipelajari dengan metode berpikir secara deduktif dan induktif. Untuk menganalisis data dari hasil penelitian digunakan teori tentang asuransi sosial bagi pegawai PT. TASPEN (PERSERO).

\section{HASIL PENELITIAN DAN ANALISA DATA}

\subsubsection{Profil PT. TASPEN (PERSERO)}

PT TASPEN (PERSERO) Kantor Cabang Utama Semarang mulai beroperasi tahun 1987, dibentuk berdasarkan Keputusan Direksi PT TASPEN (PERSERO) No.48/DIR/SK/1987 tanggal 8 Agustus 1987. Sejak awal beroperasinya, PT TASPEN (PERSERO) menggunakan gedung yang disewa di Jalan Pandanaran No.123 Semarang, dimana dengan kondisi ini akan mempengaruhi kualitas pelayanan kepada peserta karena keterbatasan sarana dan hal ini berlangsung dalam waktu kurang lebih 2 tahun.

Pada tanggal 1 Desember 1987 dilakukan peletakan batu pertama pembangunan gedung PT TASPEN (PERSERO) Kantor Cabang Utama Semarang yang terletak di Jl. Mataram 892-4 Semarang oleh Direktur Utama Taspen DRS. Ida Bagus Putu Sarge. Selanjutnya pada tanggal 3 April 1989 gedung tersebut diresmikan oleh Gubernur Jawa 
Tengah, H.M Ismail dan digunakan hingga sekarang.

\subsubsection{Resiko $\quad$ Yuridis} Asuransi Sosial Bagi Pegawai PT. TASPEN (PERSERO) Kantor Cabang Utama Semarang yang Mengajukan Pensiun Dini

Resiko yuridis adalah akibat yang ditimbulkan oleh suatu peristiwa hukum berupa sanksi. Berdasarkan hasil penelitian di PT. TASPEN (PERSERO) Kantor Cabang Utama Semarang dari hasil wawancara dengan bapak Moh. Soleh ${ }^{4}$ bahwa perjanjian asuransi sosial yang didapat oleh Pegawai PT. TASPEN (PERSERO) melekat pada saat menandatangani Surat Keputusan (SK) pengangkatan pegawai, menurut bapak Moh. Soleh yang telah disebutkan pada bagian terdahulu diperoleh gambaran data mengenai jumlah pensiun dini pegawai PT. TASPEN (PERSERO) tahun 2015 - 2017 di lokasi penelitian pada tabel 1 berikut :

Pegawai PT. TASPEN(PERSERO) Pensiun Dini Tahun 2015 - 2017

${ }^{4}$ Wawancara, Moh. Soleh, Bidang SDM PT Taspen Persero Semarang, tanggal 7 Agustus 2018

\begin{tabular}{|c|c|c|c|}
\hline Io. & Tahun & Isia & Jumlah \\
\hline l. & 2015 & 52 & 2 \\
\hline & & 50 & 1 \\
\hline 2. & 2016 & 54 & 1 \\
\hline 4. & 2017 & 48 & 1 \\
\hline & & 53 & 1 \\
\hline Total & - & - & 6 \\
\hline
\end{tabular}

\section{Sumber data: PT. TASPEN (PERSERO) Semarang}

Berdasarkan tabel 1 diatas terlihat bahwa jumlah pegawai PT. TASPEN (PERSERO) yang mengajukan pensiun dini, sejak tahun 2015 2017 yaitu 6 orang. Jumlah pegawai PT. TASPEN (PERSERO) yang mengajukan pensiun dini lebih banyak dilakukan oleh mereka yang sudah mencapai usia 46 tahun keatas. Dilihat dari waktu pengajuan pensiun dini, terlihat bahwa pengajuan pensiun dini tersebut lebih banyak dilakukan pada tahun 2015 yaitu sebanyak 3 orang, dapat dikatakan setiap tahun ada peserta yang mendaftarkan diri untuk mengajukan pensiun dini di PT. TASPEN (PERSERO) Kantor Cabang Utama Semarang, hal tersebut dapat dipengaruhi oleh beberapa faktor seperti para pegawai PT. TASPEN (PERSERO) sudah mendaftar diri ke pihak asuransi untuk berjaga - jaga hal yang akan terjadi ataupun sudah melakukan pembukaan rekening tabungan ke perusahaan Perbankan untuk masa dihari tua nantinya, 
sudah banyak cara untuk mengantisipasi kejadian yang akan terjadi dikemudian nanti.

Dalam suatu perjanjian asuransi adanya hak dan kewajiban penanggung dan tertanggung, untuk hak tertanggung adalah mendapatkan pesangon dan menerima hak - hak pensiun lainnya pada saat masa pensiun. Sedangkan kewajiban tertanggung adalah pegawai PT. TASPEN (PERSERO) wajib membayar uang iuran setiap bulan sebesar 8\% (delapan persen) dari penghasilan sebulan tanpa tunjangan pangan dimana uang tersebut diserahkan kepada penanggung yaitu pihak PT. TASPEN (PERSERO), dimana uang iuran bulanan tersebut dapat diambil atau digunakan apabila pihak tertanggung menyerahkan bukti pensiun dan akan diberikan pesangon yang telah disetujui oleh Direksi PT. TASPEN (PERSERO) tersebut.

Sementara itu hak dan kewajiban peserta Asuransi Sosial Pegawai Negeri Sipil ini diatur dalam Peraturan Pemerintah Nomor 20 Tahun 2013 Perubahan Atas Peraturan Pemerintah Nomor 25 Tahun 1981 pada Bab IV, yaitu :

a. Peserta wajib memberi keterangan secara tepat mengenai dirinya beserta seluruh anggota keluarganya;

b. Peserta wajib membayar iuran setiap bulan sebesar 8\% (delapan persen) dari penghasilan sebulan tanpa tunjangan pangan, yang terdiri dari 4 3/4\% (empat tiga perempat persen) dari penghasilan untuk Program Pensiun dan 3 1/4\% (tiga perempat persen) dari penghasilan untuk Program Tabungan Hari Tua (THT);

c. Peserta berhak Tabungan Hari Tua (THT) dan Pensiun jika diberhentikan bekerja.

Pensiun adalah kondisi ketika seseorang sudah tidak bekerja lagi. Pemberhentian atas permintaan sendiri sebelum pegawai mencapai batas usia pensiun disebut pensiun dini. Pemberhentian atas permintaan sendiri ada dua jenis yang pertama tanpa diberi hak pensiun dan yang kedua pensiun dini dengan hak pensiun.

Setiap peserta pensiun yang mengajukan pensiun dini yang memperoleh persetujuan dari Direksi PT. TASPEN (PERSERO) Kantor Cabang Utama Semarang atas permintaan diri sendiri maka pegawai PT. TASPEN (PERSERO) berhak menerima pesangon dan menerima hak - hak pensiun lainnya berdasarkan peraturan yang berlaku. Lebih lanjut terkait dengan resiko yuridis asuransi sosial bagi pegawai PT. TASPEN (PERSERO) Kantor Cabang Utama Semarang yang mengajukan pensiun dini dimana dikemukakan oleh bapak Moh. Soleh sebagai berikut : ${ }^{5}$

Setiap pengajuan pensiun dini yang telah disetujui oleh Direksi PT. TASPEN (PERSERO) dengan

${ }^{5}$ lbid. 
pengajuan usia dibawah 56 tahun maka pemberian upah pensiun kecil atau lebih sedikit sesuai dengan perjanjian yang telah disetujui. Pengajuan pensiun yang sesuai dengan ketentuan pada Peraturan Direksi PT Dana Tabungan dan Asuransi Pegawai Negeri (PERSERO) Nomor PD38/DIR/2017 Tentang Program Pensiun Dini maka pemberian upah pensiun pokok sebesar 75\% dengan dikalikan gaji pokok, adapun yang dimaksud dengan pensiun dini dalam hal ini adalah pensiun dikarenakan kondisi fisik berupa mempunyai penyakit tertentu ataupun sering sakit - sakitan, tidak cakap dalam bekerja dan lain sebagainya.

Sedangkan pada Peraturan Pemerintah Nomor 11 Tahun 2017 Tentang Manajemen Pegawai Negeri Sipil yang terkait pemberhentian karena mencapai batas usia pensiun dalam Pasal 239 ayat (2) Batas Usia Pensiun 58 (lima puluh delapan) tahun, pegawai sebelum mencapai usia tersebut sudah mengajukan pensiun dini resiko yuridis saat pengajuan pensiun dini tidak ada akibat hukum kecuali orang yang bersangkutan mengajukan pensiun dini bermasalah, pada saat pensiun akan mendapatkan sanksi administratif bisa berupa penundaan pensiun atau pesangon.

Polis asuransi merupakan sebuah bukti perjanjian tertulis yang dilakukanoleh pihak perusahaan asuransi (penanggung) dengan nasabah pengguna layanan asuransi (tertanggung), yang isinya menjelaskan segala hak dankewajiban antara kedua belah pihak tersebut. Polis asuransi akan menjadi bukti tertulis yang sah dalam perjanjian yang dilakukan oleh pihak penanggung dan pihak tertanggung.

Perjanjian PT. TASPEN (PERSERO) pemegang polis karyawan berjanji bekerja lebih baik dan disiplin sesuai prosedur, dengan ini setuju untuk membayarkan manfaat asuransi atas diri peserta (para peserta) mengacu pada syarat syarat dan ketentuan - ketentuan sebagaimana tercantum didalam ketentuan umum dan ketentuan khusus, serta addendum (apabila diadakan) yang didekatkan/dilampirkan pada polis ini yang merupakan bagian yang tidak terpisahkan dari polis ini.

Sebagaimana telah diuraikan sebelumnya terkait dengan permasalahan diatas setiap peserta yang mengajukan pensiun dini atas permintaan diri sendiri berhak menerima pesangon sejumlah uang yang diberikan oleh perusahaan kepada karyawan yang diberhentikan dengan hormat karena mengajukan permohonan pensiun dini dan menerima hak - hak pensiun sesuai dengan hak pensiun normal berdasarkan peraturan yang berlaku.

Sehubungan dengan dana pensiun yang terdapat pada PT. TASPEN (PERSERO) Kantor Cabang Utama Semarang dimana usia pensiun yang 
ditetapkan sesuai dengan peraturan tersebut dimana termuat dalam pasal 2 Peraturan Direksi PT Dana Tabungan Asuransi Pegawai Negeri (PERESERO) Nomor PD38/DIR/2017 Tentang Program Pensiun Dini yang berbunyi permohonan pensiun dini diajukan oleh karyawan yang pada saat pengajuan telah berusaia minimum 46 tahun dan berusia maksimum 53 tahun.

Dari aturan tersebut terdapat kelemahan dimana diaturan tersebut tidak diberikan penjelasan mengenai besaran yang akan diterima bagi pegawai PT. TASPEN (PERSERO) yang mengajukan pensiun dibawah 46 tahun. Kekurangan ini sangat merugikan bagi pegawai PT. TASPEN (PERSERO) yang mengajukan pensiun dibawah 46 tahun karena mereka tidak dilindungi oleh payung hukum yang jelas dengan kata lain PT. TASPEN (PERSERO) Kantor Cabang Utama Semarang dapat memberikan besaran dana pensiun dibawah yang sudah ditetapkan oleh Pemerintah, hal ini sangat merugikan pegawai PT. TASPEN (PERSERO) dan dari pihak PT. TASPEN (PERSERO) dapat keuntungan yang sangat besar tanpa memperhatikan bagaimana hak yang seharusnya diterima oleh pegawai PT. TASPEN (PERSERO) yang mengajukan dibawah aturan yaitu 46 tahun.

4.2.2 Penyelesaian Klaim Peserta Asuransi Sosial Pegawai
PT. TASPEN (PERSERO) Kantor Cabang Utama Semarang yang Mengajukan Pensiun Dini

Proses penyelesaian klaim di PT. TASPEN (PERSERO) dapat dilakukan dengan dua cara yaitu dengan cara langsung dan tidak langsung. Untuk penyelesaian klaim asuransi sosial di PT. TASPEN (PERSERO) secara langsung dengan cara peserta klaim asuransi sosial PT. TASPEN (PERSERO) yang terdiri dari pegawai PT. TASPENmendatangi langsung ketempat PT. TASPEN (PERSERO) untuk mendaftarkan diri kepada bagian penetapan klaim yang kemudian data tersebut akan diserahkan kepada kepala bidang pelayanan guna memberikan tandatangan dan Laporan Penetapan Harta (LPH) peserta setelah mendapat tandatangan data akan dicek ulang perihal LPH kemudian memberikan LPH kepada kepala bidang pelayanan untuk disahkan.

Pengelolahan berkas yang diajukan dapat berupa Surat Permohonan Pembayaran (SPP) langsung. Berkas klaim tersebut akan diproses oleh PT. TASPEN (PERSERO) Kantor Cabang Utama Semarang jika berkas yang diberikan telah memenuhi syarat. Selanjutnya, pihak PT. TASPEN (PERSERO) Kantor Cabang Utama Semarang akan mengirimkan hak peserta tersebut melalui bank (transfer).

Pengelolahan berkas yang diajukan yang dilalui peserta pada 
proses SPP Langsung terdiri dari 3 (tiga) tahapan, yaitu:

1. Antrian pertama, peserta datang ke loket informasi. Peserta yang memasuki pintu masuk PT. TASPEN (PERSERO) Kantor Cabang Utama Semarang akan disapa oleh satuan pengamanan (satpam) dan dipersilakan menuju loket informasi. Petugas yang berada di loket informasi sebanyak 1 (satu) orang. Petugas informasi akan melakukan penyeleksian terhadap dokumen dokumen peserta sesuai dengan persyaratan pengajuan klaim, seperti Surat Keputusan (SK) Pensiun, Kartu Tanda Penduduk (KTP), surat kematian, dan surat nikah. Apabila peserta sudah memenuhi persyaratan, petugas informasi mempersilakan peserta untuk mengambil nomor antrian pada mesin antrian. Selanjutnya, peserta menunggu sampai nomor antrian tersebut dipanggil oleh petugas loket penerimaan dan penelitian klaim;

2. Antrian kedua, peserta datang ke loket penerimaan dan penelitian klaim. Petugas di loket ini berjumlah 6 (enam) orang yang melakukan pemanggilan peserta berdasarkan nomor antrian. Pada loket ini, berkas klaim peserta akan diuji keabsahannya melalui proses penelitian dokumen yang diberikan kepada petugas. Jika dokumen dianggap meragukan petugas, maka peserta akan diwawancara secara mendalam oleh petugas. Jika petugas menyatakan bahwa berkas peserta tersebut sah, maka petugas akan memberikan tanda terima berkas kepada peserta untuk diberikan kepada petugas kasir. Selanjutnya, berkas tersebut akan diserahkan ke petugas di bagian updating data dan perhitungan hak. Petugas pada bagian ini berjumlah 4 (empat) orang. Pada bagian updating data dan perhitungan hak, data peserta akan dimutakhirkan, dihitung jumlah nominal hak yang akan diberikan dan hasilnya dicetak dalam bentuk Lembar Perhitungan Hak (LPH). LPH berfungsi juga sebagai bukti transaksi (voucher). Proses yang dimulai dari pengesahan berkas hingga pencetakan voucher disebut proses pelayanan 3 (tiga) titik. LPH akan diserahkan ke bagian verifikasi untuk ditandatangani pejabat penetapan hak (Kasi PK) dan otorisator (Kabid Pelayanan). Lalu, LPH akan diserahkan ke bagian Keuangan untuk disahkan oleh pejabat pengeluaran kas (Kasi Keuangan) dan pengesahan hak (Kabid Keuangan).

3. Antrian ketiga, peserta datang ke loket kasir apabila dokumen sudah dinyatakan sah. Petugas di loket ini sebanyak 2 (dua) orang petugas. Setelah peserta menerima tanda terima berkas klaim dari petugas penerimaan dan penelitian klaim, peserta akan menyerahkan tanda terima tersebut kepada petugas kasir dan menunggu untuk dibayarkan haknya. Apabila peserta sudah dibayarkan haknya, maka 
peserta meninggalkan ruang tunggu. Artinya, peserta keluar dari sistem antrian. Proses operasional penyelesaian klaim pada PT. TASPEN (PERSERO) Kantor Cabang Utama Semarang.

Kemudian akan dilakukan penelitian keaslian dokumen dari CS (Customer Service) mereka mengkaji status dan tanggungan peserta pembuatan LPH. Setelah dilakukan penelitian mengkaji akan dilakukan pemeriksaan SPP (Surat Permintaan Pembayaran) peserta diterima atau tidak jika SPP diterima maka klaim asuransi sosial dapat dilakukan oleh peserta klaim asuransi sosial PT. TASPEN (PERSERO) itu sendiri jika SPP ditolak maka peserta asuransi tidak dapat melakukan klaim tersebut.

\subsubsection{Hambatan - Hambatan yang Dihadapi Oleh Peserta yang Mengajukan Pensiun Dini di PT. TASPEN (PERSERO) Kantor Cabang Utama Semarang}

Peraturan Pemerintah Nomor 20 Tahun 2013 tentangAsuransi Sosial Pegawai Negeri Sipilmenegaskan bahwa "Penyelenggara Asuransi Sosial adalah Negaraatau Suatu Organisasidibawah Wewenang Negara”.

Berdasarkan Peraturan Pemerintah tersebut sudah jelas bahwa program pensiun dini ditawarkan sukarela kepada karyawan PT. TASPEN (PERSERO) yang telah memenuhi persyaratan tertentu untuk mengajukan permohonan berhenti bekerja sebagai karyawan atas permintaan sendiri secara sukarela, yang selanjutnya disebut pensiun dini.

Lebih lanjut terkait dengan permohonan pensiun yang dikemukakan oleh bapak Moh. Soleh selaku SDM PT TASPEN (PERSERO) : ${ }^{6}$

Adapun hambatan - hambatan yang dihadapi oleh peserta dalam mengajukan pensiun dini dimana hambatannya meliputi:

a. SK Pemberhentian dengan hak pensiun atau tidak terbit melampaui tanggal pemberhentian, hal ini biasanya terjadi karena penerbitan SK Pemberhentian melalui proses yang panjang;

b. Lamanya penerbitan SK Pensiun Dini tersebut mengakibatkan Pegawai PT. TASPEN (PERSERO) mengajukan Pensiun juga terlambat ke PT. TASPEN (PERSERO);

c. Oleh karena SK Pensiun Dini berpotensi terlambat maka memberhentikan gajinya karena belum ada kepastian bulan diberhentikan sehingga kemungkinan keterlanjuran bayar gaji;

d. Keterlambatan pengajuan Pensiun mengakibatkan pembayaran klaimnya oleh PT. TASPEN (PERSERO) kepada Pegawai mengalami keterlambatan;

\footnotetext{
${ }^{6}$ Wawancara, Moh. Soleh, Bidang SDM PT Taspen Persero Semarang, tanggal 7 Agustus 2018
} 
Suatu perjanjian dari beberapa hambatan yang telah dikemukakan oleh bapak Moh. Soleh diatas maka calon peserta pengajuan pensiun harus mengetahui bagaimana prosedur pengajuan pensiun di PT. TASPEN (PERSERO) Kantor Cabang Utama Semarang dimana telah ada didalam Peraturan Direksi PT Dana Tabungan dan Asuransi Pegawai Negeri (Persero) Nomor PD-38/DIR/2017 Tentang Program Pensiun Dini, dimana pengajuan dilakukan minimum umur 46 tahun dan maksimum 53 tahun, jika pengajauan dilakukan dibawah usia minimum akan ada kemungkinan akan sulit mendapatkan persetujuan dari Direksi. Karena persetujuan pensiun dini dilakukan atau diambil melalui rapat Direksi dimana pengajuan pensiun dini dapat disetujui, ditunda atau ditolak. Jika pensiun dini yang diajukan ditunda atau ditolak maka Pegawai PT. TASPEN (PERSERO) yang bersangkutan tetap menjalankan tugas dan tanggungjawabnya pada unit kerja semula sampai dengan batas waktu penundaan pensiun dini yang telah disetujui oleh Direksi.

\section{SIMPULAN DAN SARAN}

\subsection{Simpulan}

Dari hasil penelitian diatas maka dapat disimpulkan sebagai berikut :

1. Pegawai PT. TASPEN (PERSERO) yang mengajukan pensiun dini dan tidak memenuhi syarat pensiun tidak berhak uang pensiun bulanan dan Tabungan Hari Tua (THT), namun yang bersangkutan diberikan Nilai Tunai THT dan nilai tunai iuran pensiun;

2. Hambatan - hambatan yang dihadapi oleh peserta dalam mengajukan pensiun dini hambatannya meliputi:

a. Keterlambatan pengajuan dan penerbitan SK Pensiun dini;

b. Berpotensi terjadi keterlanjuran gaji Pegawai PT. TASPEN (PERSERO) sebagai akibat keterlambatan penerbitan SK Pensiun dini;

c. Berpotensi keterlambatan pembayaran THT dan Pensiun kepada Pegawai PT. TASPEN (PERSERO)

3. Proses penyelesaian klaim di PT. TASPEN (PERSERO) dapat dilakukan dengan dua cara yaitu dengan cara langsung dan tidak langsung. Untuk penyelesaian klaim secara langsung dengan mendatangi langsung ketempat PT. TASPEN (PERSERO) untuk mendaftarkan diri kepada bagian penetapan klaim dengan membawa langsung berkas tunai pada hari yang sama ketika peserta mengajukan klaim.

\subsection{Saran}

Saran yang perlu dipertimbangkan dalam proses pensiun dini, antara lain:

a. SK Pensiun bagi pegawai PT. TASPEN (PERSERO) yang 
mengajukan pensiun dini tidak berlaku surut;

b. Selama pegawai PT. TASPEN (PERSERO) belum disetujui atau SK Pensiun Dini terbit pegawai PT. TASPEN (PERSERO) masih berhak gaji bulanan;

c. Pembayaran hak bagi pegawai PT. TASPEN (PERSERO) yang pensiun dini agar dilakukan secara otomatis oleh PT. TASPEN (PERSERO) sehingga yang bersangkutan lebih nyaman hidupnya.

\section{DAFTAR PUSTAKA}

Buku:

AM. Hasan Ali, 2004, Asuransi Dalam Perspektif Hukum Islam, Prenada Media, Jakarta.

Abdulkadir Muhammad, 2011, Hukum Asuransi Indonesia, Citra Aditya Bakti, Bandung.

Amiruddin, 2013, Pengantar Metode Penelitian Hukum, Raja Grafindo Persada, Jakarta.

Bhisma Murti, 2000,Dasar-Dasar Asuransi Kesehatan, Kanisius, Yogyakarta.

C.S.T. Kansil dan Cristine S.T. Kansil, 2006, Kitab Undang Undang Hukum Perusahaan jilid 1, Pradnya Paramita, Jakarta.
Djumadi, 2008,Hukum PerburuhanPerjanjian Kerja, PT Rj Grafindo Persada, Jakarta.

D.S. Hansell dalam Sri Rejeki Hartono, 2005, Hukum Asuransi dan Perusahaan Asuransi, Sinar Grafika, Jakarta.

Herman Darmawi, 2004,Manajemen Asuransi, Bumi Aksara, Jakarta.

H. Gunanto, 2003,Asuransi Kebakaran di Indonesia, Logos Wacana Ilmu, Tanggerang.

HMN Purwosutjipto, 2003,Pengertian Pokok Hukum Dagang Indonesia Jilid 6,Djambatan, Jakarta.

Hartanto Wirawan, 2004,Pengertian Asuransi, Diktan Kuliah Mercubuana, Jakarta.

Kasmir, 2008,Bank dan Lembaga Keuangan Lainnya, Raja Grafindo Persada, Jakarta.

Kun Wahyu Wardana, 2009,Hukum Asuransi, CV. Mandar Maju, Bandung.

Radiks Purba, 2011,Memahami Asuransi di Indonesia, Pustaka Binaman Pressindo, Jakarta.

Soerjono Soekanto dan Sri Mamudji, 2010,Penelitian Hukum Normatif, Suatu Tinjauan 
Singkat,Raja Grafindo Persada, Jakarta.

Sri Susilo Y. dkk, 2000, Bank dan Lembaga Keuangan, Salemba Empat, Jakarta.

Sri Rejeki Hartono, 2005, Hukum Asuransi dan Perusahaan Asuransi, Sinar Grafika, Jakarta.

Sentosa Sembiring, 2014,Hukum Asuransi, Nuansa Aulia, Bandung.

S.R. Diacon dan R.L. Carter dalam Sri Rejeki Hartono, 2005,Hukum Asuransi dan Perusahaan Asuransi, Sinar Grafika, Jakarta.

Zulaini Wahab, 2005,Segi Hukum Dana Pensiun, PT RajaGrafindo Persada, Jakarta.

\section{Wawancara}

Wawancara dengan Bapak Moh. Soleh staff Bidang SDM PT Taspen Persero Semarang, pada tanggal 7 Agustus 2018, pukul 09.00 WIB, PT Taspen Persero Semarang.

\section{Peraturan}

Peraturan Pemerintah Nomor 20

Tahun 2013 Tentang Asuransi Sosial

Pegawai Negeri Sipil. 